\title{
India blocks sale of transgenic cotton seeds
}

\section{K. S. Jayaraman, New Delhi}

India has halted the commercial release of a genetically modified (GM) variety of cotton just two months after it became the first transgenic crop to be approved as safe by government scientists.

In a potentially serious setback for the global acceptance of GM crops, India's environment department declined to approve the commercial use of a cotton variety developed by Monsanto and its Indian subsidiary, Maharashtra Hybrid Seed Company (Mahyco). The department said it was not fully convinced of the biological safety or economic benefits of the variety, and has ordered fresh trials.

The decision is a snub for India's Department of Biotechnology (DBT), which had earlier said the cotton was safe and had recommended large-scale cultivation.

The cotton variety in question carries Monsanto's proprietary gene from Bacillus thuringiensis $(B t)$, which confers protection against the deadly bollworm (Helicoverpa

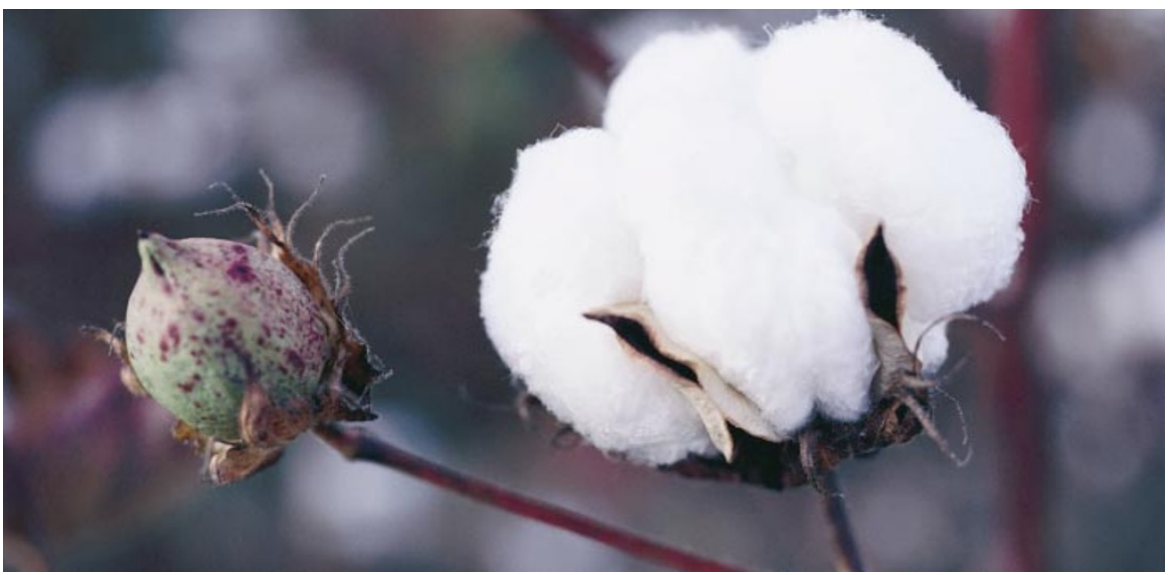

Nipped in the bud: India's approvals committee wants cotton trials to be conducted on a larger scale.

armigera). Almost $40 \%$ of pesticide use in India is aimed at controlling this single pest. India accounts for more than $15 \%$ of the world's cotton supply, and Monsanto says the use of $B t$ cotton will increase production and cut the use of chemical pesticides.

\section{Curbs at NIH frustrate travel plans}

\section{Corie Lok, Washington}

Thousands of researchers working for the intramural programme of the National Institutes of Health (NIH) could have their travel plans curtailed under reporting rules imposed by the US health department.

Travel to meetings that are to be attended by five or more NIH intramural employees must now be approved in advance by the office of Tommy Thompson, secretary of the health department of which the NIH is part. Any trip costing more than $\$ 2,500$ must be similarly approved. And travel to international meetings on AIDS and other infectious diseases, as well as visits to certain countries, including China and South Africa, also require central approval.

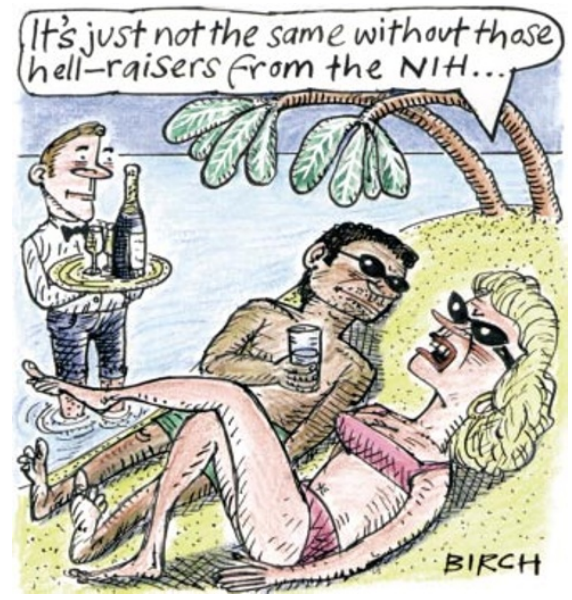

The rules on international travel were quietly implemented by the department in March and were extended last month to include domestic travel. Previously, NIH's postdoctoral employees needed only to clear their travel plans with their own institute.

Senior NIH officials say the rules simply reflect the new administration's attempts to gather information on travel. But scientific societies fear they will prevent researchers from attending conferences and doing their work effectively.

“There's concern both within NIH and outside that these rules will have a negative impact on the ability of scientists to freely exchange ideas with their colleagues in the government," says Martin Frank, executive director of the American Physiological Society. Frank says he has received complaints from NIH scientists and that his society plans to send the health department a letter about its concerns.

"It's hard keeping up with scientific research anyway," says Tony Mazzaschi of the Association of American Medical Colleges. "To add another hurdle is really untenable. I hope the rules are short-lived."

Campbell Gardett, a spokesman for the health department, said the rules were drawn up to look at questions about travel to glamorous places and the need for several government employees to attend the same meeting. "Travel should not be frivolous," says Gardett. "It should be necessary."
Since 1998, Mahyco has conducted field trials of the cotton in 52 locations, under DBT supervision. After getting the go-ahead from the department, Mahyco sought the required approval from the environment ministry's Genetic Engineering Approval Committee (GEAC) for commercial cultivation.

But the committee said on 19 June that the trial data were unreliable, as the crops were grown off-season when the pest load was naturally low. It asked the company to repeat the field trials on a larger scale - this time under the supervision of the Indian Council of Agricultural Research (ICAR).

Although the decision is a blow to Mahyco, which has spent US\$8 million over 6 years to develop the cotton, managing director Raju Barwale says that the company "looks forward to continue working closely with all government agencies and the ICAR in order to make this technology available to Indian farmers as soon as possible".

Sources close to the committee say that concerns about managing bollworm resistance raised by Greenpeace International science adviser Doreen Stabinsky played a part in its decision. They add that officials from India's health ministry also had reservations about the proposed use of a streptomycinresistance gene as a marker, as this could potentially render the antibiotic useless.

The GEAC ruling has been welcomed by environmental groups such as the Delhibased Research Foundation for Science, Technology and Ecology, which said in a statement: "Giving clearance would have opened the floodgates of other GM seeds and crops, when India does not have the appropriate technical and scientific infrastructure to deal with the risks of genetic engineering."

Kuldip Chopra, research director of Mahindra, another company that is developing herbicide-resistant corn, said: "We do not know the full facts but we had expected that Mahyco's cotton would at least receive permission for limited commercialization." 